\title{
TRANSNATIONAL IMAGINARIES OF EMERGING IDENTITIES IN ENGLISH TEACHER EDUCATION IN A PERIOD OF ACCOMMODATION TO SOCIAL CHANGE IN BRAZILIAN HIGHER EDUCATION
}

\author{
IMAGINÁRIOS TRANSNACIONAIS DE IDENTIDADES \\ EMERGENTES NA FORMAÇÃO DE PROFESSORES DE \\ LÍNGUA INGLESA EM PERÍODO DE ACOMODAÇÃO EM \\ MUDANÇAS SOCIAIS NO ENSINO SUPERIOR BRASILEIRO
}

\section{Souzana Mizan*}

\begin{abstract}
Between 2003 and 2014, the Brazilian government adopted a public policy of expansion within Brazilian Higher Education, to strengthen processes of social inclusion. This included the construction of new campi in far-from-the-shore cities within Brazil's interior. This study took place in one of these campi, which is located in a peripheral city of a big metropolis, where an English Teacher Education course was established in 2009. The course - academic writing for English teachers - aimed to develop students' writing together with their critical thinking. It is from this academic writing course that this research emerges. The pedagogy of writing suggested in this article is based on Giroux (1988) and Freire (2005). As such, it conceives of writing as an epistemology, a mode of learning that seeks to find "the thematic universe" or "the cluster of generative topics" that the students wished to research and write about (FREIRE, 2005, p. 101). The process pursued the investigation of the students' way of thinking of the "real" in the educational context through written language. The texts produced by students revealed transnational imaginaries and literacies that rupture the dominant model of transnational movements, physical or virtual. In this context, I believe that the ethnographic approach adopted by the course to investigate the cultures and literacies of this community of students contributed to the development of the students' academic writing skills and to an exchange of world views among the students and teacher that enriched the classroom as a learning space.
\end{abstract}

Keywords: academic writing; critical approach; transnational literacies.

\section{RESUMO}

O governo brasileiro adotou entre as anos 2003-2014 a política pública de expansão do ensino superior brasileiro para fortalecer processos de inclusão social. Nesse espírito, o governo implementou a construção de novos campi em cidades distantes do litoral. Este estudo ocorreu em um desses campi, localizado em uma cidade periférica de uma grande

\footnotetext{
* Universidade Federal de São Paulo (UNIFESP), São Paulo, SP, Brasil. souzana.mizan@unifesp.br
} 
metrópole, onde o curso de Formação de Professores de Inglês teve início em 2009. O curso de redação acadêmica para professores de inglês teve como objetivo desenvolver a escrita dos alunos junto com seu pensamento crítico. A pedagogia da escrita que estamos sugerindo, baseada em Giroux (1988) e Freire (2005), concebe a escrita como uma epistemologia, um modo de aprender buscando encontrar o "universo temático" ou "o conjunto de temas geradores" sobre os quais os alunos queriam pesquisar e escrever. $\mathrm{O}$ processo de escrita buscou a investigação do modo de pensar dos alunos sobre o "real" no contexto educacional por meio da linguagem escrita. Os textos produzidos pelos alunos revelaram imaginários e letramentos transnacionais que trazem rupturas ao modelo dominante de movimentos transnacionais, sejam eles físicos ou virtuais. Nesse contexto, acreditamos que a perspectiva etnográfica adotada pelo curso para investigar as culturas e letramentos dessa comunidade de alunos contribuiu para o desenvolvimento das habilidades de redação acadêmica dos alunos e para a troca de visões de mundo entre os alunos e a professora, que enriqueceram a sala de aula como espaço de aprendizagem.

Palavras-chave: escrita acadêmica; abordagem crítica; letramentos transnacionais.

\section{INTRODUCTION: TRANSNATIONAL LITERACIES AND LANGUAGE EDUCATION IN POSTMODERN GEOGRAPHIES}

The Brazilian government, in its efforts to make education more democratic in a country where historically the majority of its citizens don't have access to public higher education, adopted from 2003 to 2014 (BRASIL, 2014) a public policy of expansion for Brazilian Higher education. Through the process of interiorization of Brazilian Federal Universities -in other words, through the construction of campi in smaller cities and rural areas -the Brazilian Ministry of Education (BRASIL, 2014), aimed at reducing situated social inequalities and enhancing regional development by decentralizing physically and geographically the public institutions of higher education, over a ten-year period. This study took place in one of these new campi, which is located in a peripheral city of a big metropolis in which a course of English Teacher Education started in 2009.

The social field of interest in this paper is that of language education and literacy in peripheral urban spaces in a South American space. Although globalization and transnational literacies are seen as provoking physical or virtual contacts between people in different nations, this research shows that transnational education and literacy through a global language can take place in other ways, too. Therefore, this approach calls into question common juxtapositions between the local and the global, center and periphery, homogeneity and heterogeneity inside and outside national borders.

In current times, we have been reflecting on notions of place and space in new ways. Globalization processes, for example, led by "the development of 
communications and transport technologies" (HELLER, 2011, p. 19) have not only integrated local and regional markets into global ones but also "intensified and compressed the circulation of people, goods, and information" (HELLER, 2011, p. 20). However, for many nations, globalization seems to pose a threat to national culture and identity. Thus, nations seeking to protect their communities and traditions have given rise to different forms of nationalism in contemporary times.

In many cases, transnational literacies imagine a global citizen, usually seen as a privileged member of the society, who crosses physical, cultural, linguistic and epistemological borders with an openness to the new and the unknown (THE RIO TIMES, 2017). However, this idyllic representation of flows not only of products, but also of cultures, languages and people tends to leave out the millions of cosmopolitans that do not belong to the elite, but move out from their local contexts to escape local regimes and wars, or to work as cheap labour. Transnational identities may carry prestige or not depending on the conditions of the transnational movement. Still, this is not the main type of transnationalism we will be referring to in this paper.

García and Wei (2014) develop 'a trans' approach to language and education where space is an important player, without having a concrete existence. This approach conceives of a "trans-system and trans-spaces; that is, to fluid practices that go between and beyond socially constructed language and educational systems, structures and practices to engage diverse students' multiple meaning-making systems and subjectivities" (p. 3). Warriner (2007), on the other hand, subscribes to and, at the same time, contests this notion of deterritorialized space, "detached from local places and embedded in the imaginings of people" (p. 204). Low and Lawrence-Zuniga (2003, p. 25) refer to "transnational spaces" to encompass global, transnational and translocal spatial formations. And they explain the translocal in the following terms:

Globalization also radically changes social relations and local places due to interventions of electronic media and migration, and the consequent breakdown in the isomorphism of space, place, and culture. This process of cultural globalization creates new translocal spaces and forms of public culture embedded in the imaginings of people that dissolves notions of statebased territoriality.

A 'trans' approach to nationalism and literacies deconstructs traditional notions of national space and education and reads trans-spaces and literacies as fluid practices taking place in traditional and nontraditional contexts. More dynamic views of transnationalism should reflect on the complexity of how the transnational 
movement of bodies, languages and cultures takes place. The logics of location, movement and identity are not homogeneously distributed in the global capitalist space. The nation, as place, is a heterogeneous, fluid space with transnational literacy contacts and interactions happening in its interstices.

García and Wei (2014) take this notion even further by theorizing that we have entered a new way of being in the world, "a world with Other spaces that are neither here nor there" (p. 9). Therefore, they are keen on making a critique of nation-state/colonial language ideologies by excavating subaltern knowledges (ibid.). For Makoni and Pennycook (2007), national languages should be treated as mechanisms that serve nation-state interests. To that end, the linguistic repertoires we refer to in this article are performed in different trans-national spaces and can appear as concrete, virtual or imaginary.

The concept of transnationalism might take on different meanings for cosmopolitans from the periphery or cosmopolitans from below. Transnational literacies in a globalized world seek the "disinvention" of the nation as a unit of thought in a world where information and knowledge circulate virtually instead of having bodies crossing boundaries. Transnational literacies might ask us to consider not only spaces in-between nations but also beyond such social structures that are inventions of modernity. Going beyond national space to create translocal spatial formations that don't necessarily have a physical presence, but can be the digital, the library or your imagination that connects you to your ancestors, as the writings of the students who participated in this academic writing course showed. Intercultural contact can emerge from these translocal "contact zones" (PRATT, 1992) and make students think critically about their realities and of those situated in other spaces.

This attitude towards transnational literacies demands a postmodern approach to geography (SOJA, 1989). Critical human geographies should understand transnational movements in a translocal manner that dissolves national boundaries and makes other cultures accessible not only by crossing to other national territories but also through teaching materials, libraries, and invisible mental processes.

\section{ACADEMIC WRITING IN TEACHER EDUCATION REIMAGINED: FROM STRUCTURE TO NARRATIVES OF EXPERIENCE}

A praxis approach underpins this study, since it aims toward the "practical exploration of the relation between philosophy and the world, so as to bring about real and progressive change in people's lives." (IRWIN, 2012, p. 8) Key texts 
considered during the teaching of this academic writing class were Giroux's Teachers as Intellectuals: toward a critical pedagogy of learning and Freire's Pedagogia do Oprimido. Giroux (1988) determines that there are three major approaches to the teaching of writing nowadays. The first one is the "technocratic school", a formalistic, bottomup approach that puts strict emphasis on rules while seeing writing as a craft, a technique. This approach stresses grammar and emphasizes the coordination and development of larger syntactical structures. Its flaws are that it fails "to ground the pedagogy of writing in a conceptual framework that allows students to make connections between what Vygotsky has called the inner speech and elaborated written speech" (p. 56) and fails "to perceive that writing is a process, a unique mode of learning that corresponds to powerful learning strategies that examine the complex relationship among the reader, the subject, and the writer" (p. 56). The "technocratic school" is seemingly influenced by modern ideas of linearity in education and for this reason pursues the creation of a coherent system (the one people in the West call curriculum) that can homogenize the process of the acquisition of knowledge in any context.

The second school of writing education Giroux speaks of is the "mimetic" one with its top-down approach that has students read the works of "reputable" authors in order to learn how to write by reading books that serve as models of good writing. This is true for many illustrious writers who attribute their writing to the direct influence of other writers. However, reading the work of reputable authors doesn't guarantee that one will be able to write any better and this implies that writing well might be something inborn (GIROUX, 1988).

The third approach, the "romantic school," rests on the premise that there is a causal relationship between making students "feel good" and improving students' writing abilities. It perceives writing as the product of a release of joyful emotion and believes in the worthiness of the individual's capacity to grow and realize selffulfillment. Nevertheless, it fails to realize that success is not just a matter of will; in reality, "success" represents an ability to deal concretely with the forces that generate doubt, conflict, anguish, and the possibility of making mistakes (GIROUX, 1988).

Regardless of the exposition of Giroux's categories on teaching writing, this paper does not apply a strict demarcation of teaching/ learning approaches in the academic writing classroom under questions. These approaches coexist and redefine each other through the teaching materials we use, through our approach to the concept of "mistake" (in its linguistic aspect) and the relations of power we construct in the academic community. The classroom dynamics can come to occupy 
a space "in-between" these approaches by making future teachers of English feel confident about their ideas in relation to the themes they are writing about and their capacity to express these ideas in a written academic manner.

Following the categorization of the different schools of writing, Giroux (1988) proposes a pedagogy of writing that sees penmanship as an epistemology, a mode of learning. His pedagogy views writing as a dialectical process rather than an instrumental skill and examines the writing process as a series of relationships between the writer and the subject, between the writer and the reader, and between the subject matter and the reader. Giroux's redefinition of the pedagogy of writing suggests not only differentiating between oral and written communication inside the classroom, but also discarding the notion of writing as a drill in the mastery of techniques. Writing, in Giroux's approach, is conceived as an active relationship that mediates between the subject (the writer or reader) and the world. Such a relationship has important implications about the form and content of learning, especially with respect to the concept of critical thinking.

In spite of considering the contextual constraint of offering the academic writing course in the English language studies of a reputable university, Bourdieu (1991) kept reminding me that schools are permeated with institutional norms and practices that are complicit with the power structures of dominant societies (in GARCÍA \& WEI, 2014, p. 47). Initially, Brazil, as a colonized and post-colonial space, learned Portuguese, the language of its colonizers. Nowadays, because of the spread of the English-speaking culture, it needs to learn the language of the "colonizer of human minds." (NGUGI, 1986).

The role of English language as a vehicle for globalization has gained it a mobile, deterritorialized character. As Canagarajah (2013) admits:

...contexts are overlapping, porous, and even conflictual. Rather than governing language, they are reconstructed by language. We need a more complex and dynamic orientation to context in order to understand the spatiotemporal mobility of English. English flows across layered and changing contexts, traversing competing norms and values, to take on new grammars and meanings (p. 153).

The trans-local interactive spaces that students reported to have created allude to social practices that are constructed in urban contexts. Although educational systems are usually seen as instruments of the nation-states, by using the powerful language of the state, the students had their trans-local literacies situated in spaces that sometimes operated in a local level, and other times in a national or transnational levels. Aside from the classical example of transnational literacies acquired by bodies moving concretely across national spaces, students' writings 
brought forth more unconventional movements that promoted transnational literacies. One of the students, for example, taught herself English by regularly visiting the local library. Another experienced cultural difference by teaching Syrian refugees the Portuguese language. People situated in different local spaces and interpelated by national educational systems might seek (un)conventional transnational literacies and cultural flows. These transnational relations whose type, scale and scope vary, point to complex linguistic interactions across national territories and beyond national borders, that are capable of liberating the voices of non-dominant communities.

The transnational literacy practices featured in this study emerge from a student blog called "Academic writing and the Self: having your voice heard." During the semester, students posted reflections on this blog, revealing within their blog-posts literacy practices that cross national borders and experiences that expand the local. Although most of the students cannot afford "real" transnational movements, they develop practices that give them access to cultures and languages with which they feel an affinity.

Adopting an ethnographic approach to the students' narratives helped to create distance from positivist frameworks, allowing themes to emerge naturally during the research. The experiences of the students revealed unconventional trajectories in which their communities seek out transnational literacies. Although students did not use the term "transnational" in their narratives, the interpretation of their writings in this study leads to a conceptualization of these trajectories as such,

Inspired by Alcoff's (2010) position that "post-positivist accounts of identity have made significant arguments about how to understand the mediated character of experience within a realism that validates the epistemic role of experience" (p. 152), the first topic discussed in class was "Identity and writing." The students were asked to answer the question, "How does your identity affect what you want your writing to be about?" The students' construction of their own identity revealed multiple planes of translocal experiences. 


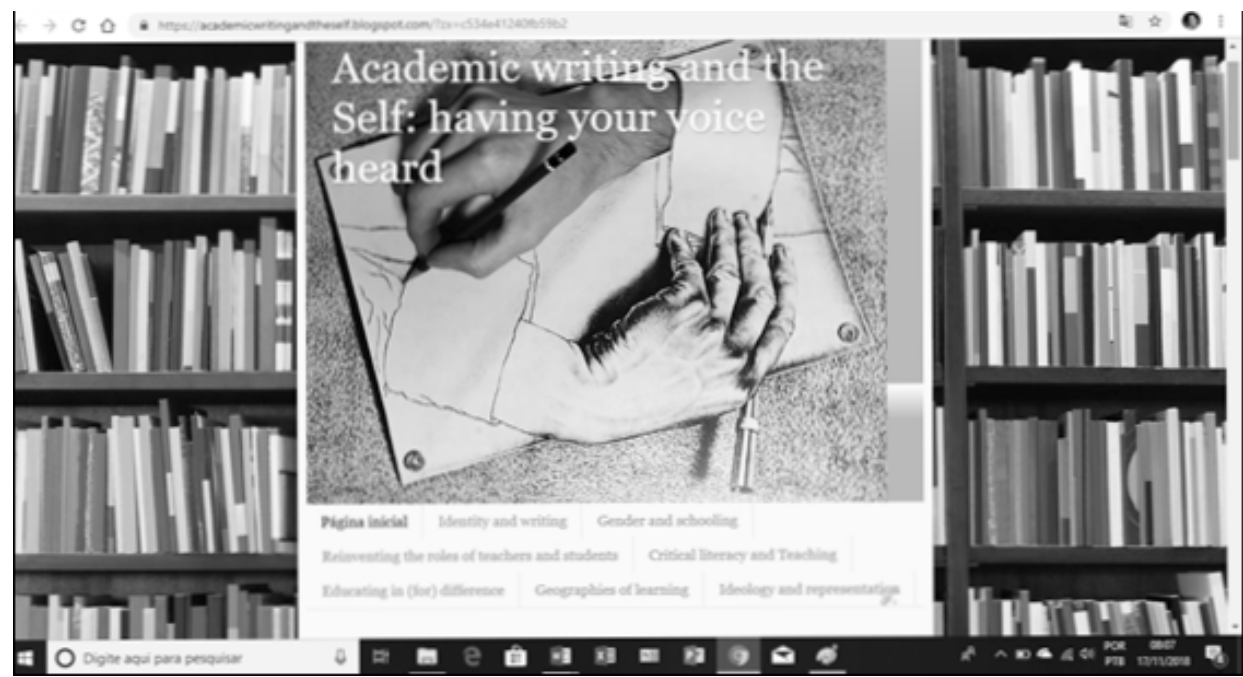

Fig 1. The blog

Hellen ${ }^{1}$, for example, reported having been part of transnational spaces which are being created by the globalizing economy that makes "people move across borders creating new transnational spaces and territorial relationships" (LOW \& LAWRENCE-ZUNIGA, 2003, p. 25). However, in spite of perceiving her identity as fluid and hybrid, essentialist views of identity still permeate her discourse:

My identity has been through a lot of things in these past years, for example when I lived abroad for a year... Identities are not fixed properties, they change all the time, just like mine did. I usually pictured me as a Brazilian girl, and I am still that girl, but with some changes. At the beginning I was afraid to lose my identity and who I am, but as the year passed by I figured out that no matter what happened to me, deep down I would still be the girl I have always been. Of course that are somethings that change along the way, but this is just the consequence of two cultures together, and when the year finished I was a little different, I grew up, and I was a Brazilian girl in touch with the American culture.

On the other hand, Fernanda described a whole different kind of transnational process that gave her access to an English language and culture. This process included choosing to learn English instead of the keyboard, two of the wishes she has had since she was a little girl. Fernanda's limited access to finances did not stop her from making choices and steering her life towards the direction she dreamed of taking:

1. All names have been changed and are fictitious. 
Unfortunately, we live in a society where people don't believe in themselves. They think they don't have the capacity to do things because they don't have money. I had to prove that kind of thought was wrong. So, I preferred to start learning English first. Every week, I went to the library to get books and magazines and I read a lot every day. Some years later, I had the opportunity to get in English course to improve my learning. It wasn't easy, but I got it.

Fernanda's trips to the local library bring forth other kinds of itineraries people trace in local spaces to access transnational literacies and cultures. On the other hand, Samantha's transnational literacies were acquired at home, in São Paulo, through her teaching contact with refugees:

I work as a Portuguese teacher, so I can be in contact with different "kinds" of people, which is very important to me, because I can deconstruct some stereotypes. I am working with migrants of many countries, as a volunteer teacher and my students are refugees, mainly of Syria. They passed for a lot of troubles to get in Brazil to try to reconstruct their lives.

This fact is very important in my life, because, I am reflecting some things that I didn't think before, as the difficult situation of refugees in Brazil, including prejudices and violence. Now, I can see the contrast of other societies, not only Brazilian society.

Other students' transnational literacies were cultivated at home, since their parents have been immigrants to Brazil and passed on to their children the language and culture they brought with them:

I was born in Brazil and lived all my life until now here. But, since I was a child, I realize that my creation was different from other children. And even at my own house. I concluded that, because my parents are Japanese. As a traditional Japanese family, we have some different habits from Brazilians in many aspects (food, discipline, etc.). As an example, I will bring to you a memory of my childhood that I never forget. When I was ten years old, I went to the bakery with my mother and on the way there, she gave me a candy. I ate the candy and threw the package away on the floor. She made me catch it up and hanged it out until I find a garbage.

Similarly, Jack shared his thoughts about how his sense of identity relates to an ancestral past. The imagination in this case is perceived as a place where a certain "reality" is experienced that produces the desire for transnational literacies and consequently motivates Jack to seek knowledge in relation to the Celtic history and culture that he experiences a connection with:

During my childhood, History was my favorite subject. Studying History many years later I found the defining element of my identity as a student: a historical connection between my family and an ancient Celtic tribe. It was the first time I could feel related to a group of countries and their culture. I started to study occupied nations and minorities influenced by this connection, with hope of writing about their respective causes and national movements.

The definition of an appropriate unit of analysis is central to the exercise of situating transnational literacies. Should the unit be the individual, the household, 
transnational organizations, the global system, or all of the above? (GUARNIZO \& SMITH, 1998, p.24-25). Students' writings revealed that transnational movements can be concrete or imaginary and the journeys towards accessing other languages and cultures can happen locally, facilitated by technology and especially by the linguistic and cultural tools provided by the internet.

\section{THE STUDENTS' THEMATIC UNIVERSE - TOWARDS A CRITICAL CURRICULUM}

The western educational system, influenced by the modern way of thinking, has separated knowledge in different areas of cognition or disciplines (disciplining the minds by organizing knowledge) and established that the acquisition of knowledge should be obtained through a universal, "logical" and gradual system of content delivery (SILVA, 1999, p. 24; DUBOC, 2013). However, these systems of gradual acquisition of the different knowledges do not take into account the diversity of contexts in which students and teachers are called to construct knowledge together.

Being shaped by these trends in education, the Western model of schooling has mainly addressed issues of content, of what should be taught in schools and universities, that has led to the construction of the concept of the curriculum. Selected knowledge, chosen by the intellectual classes, becomes official and institutionalized, or seen as the only possible way of studying any subject matter. Curriculum planning, by and large, imagines an abstract situation, in an abstract place, with abstract participants - students and teachers, as the approval of the National Curriculum Parameters (Base Nacional Comum Curricular) by the National Education Council proves. By the same token, the logic is that scientific knowledge should appreciate abstract thinking, by considering theorizing as superior to practical kinds of knowledge. To put it in other words, the absolute "reason" that constructs the curriculum succeeds to set forth an absolute truth, which is the knowledge needed to be acquired by the students who will have as their mission as future citizens to serve their nation and their nation's economy.

The practice of teaching, enchanted with its own history and conventions, resists the introduction of narratives, literary or autobiographical, that describe and explore other kinds of experiences. The recent attempt for democratization of the Brazilian Higher Education through a system of racial and social quotas is an open declaration of the historic inefficiency of the Brazilian public schooling system. However, the higher education overhaul did not prepare the ground inside the universities for such affirmative actions. Neither public universities nor their 
teaching staff got a chance to reflect on their historic policies, pedagogies and content, so that new populations were exposed to old, ill-fitting pedagogies.

The interactions that emerged from the merge of elite university knowledges with the knowledges brought by social groups that previously didn't have access to Brazilian Higher Education has not been idealistic but quite materialistic. The ideals of equality and justice have become real questions in curriculum content, in the materiality of the linguistic repertoire of our students and in the performativity of power relations inside the institution. These questions are the cultural manifestations of encounters with difference in the Higher Educational System. It would be unsound to perceive these encounters with difference as unilateral or to assume that those most effected are the students that have contact with texts and discourses that are not part of their realities. Questioning the persistence of this unilateral flow of historically validated, yet frozen educational content and practices has become vital in this period of the so-called accommodation to the changes brought up by the transition to a more democratic access to Higher Education.

Educators and institutions seeking the emotional and intellectual well being of their students need to reflect on a more multilateral exchange of knowledges. The institution and its teachers should permit the broadening of perspectives by means of the engagement in the classroom with texts and discourses that have historically suffered exclusion from the university context. The hybridization of the "Cartesian curriculum" and its discourses seems to be one of the changes we should reflect and act upon.

In turn, the students newly included by the democratization of Brazilian third level education have a different take on their academic reality to their traditionallyincluded counterparts. This former group glean understanding from their social communities as well as their classroom discourses, leading them to develop lines of inquiry that are unique within the Brazilian third level classroom. Additionally, critical trends in education increasingly encourage students from across the social spectrum to try to be critical of the literary, aesthetic and scientific canon of the traditional university curriculum.

The theories on a post-colonial curriculum take seriously Paulo Freire's conviction that the subjugated, by being in the position of the dominated in the structure that divides the society in dominant and subjugated, have an epistemological privilege (SILVA, 1999, p. 62), on the grounds that they get to see and know the world entangled in the structures of dominance in a way that the dominant cannot experience. It was in this spirit that Freire proposed a new pedagogy rooted in the life of these "subcultures", from them and with them (FREIRE, 2005, p. 8). 
Opening up the classroom to talk and write about experiences the students have had inside the educational system became a journey founded on the reflections of this type of critical pedagogy.

Although the government has forbidden the inclusion of the gender issue in the curriculum, by claiming that advocates of this position push for gender ideology and this might affect the traditional Brazilian family, one of the first topics discussed in class was Gender and Schooling. We opened up our discussions by analyzing Shyam Selvadurai's short story "Pigs can't fly", in which he describes the events that led him at the age of eight to realize he wasn't like the other boys. After that, we watched Hollysiz's video clip "The light"2, in which the father who scolds his son for wearing dresses ends up using a dress himself as a sign of solidarity with his son. The narratives of the participants in the course again revealed how they reflect on the topic by interacting with media and resources that cross national boundaries. Felipe, for example, mentioned a paradigm of educational approach on gender practices in Sweden:

One good example to show this difference in society has been working in Sweden. The European country decided to fight against stereotypes working with many things, such as, asexual dolls, adapted activities, the educators are instructed not to use "he" or "she" to speak to students, books used in classes are adapted against gender difference. However, we can ask: in Brazil, to fight against gender stereotypes, as in Sweden, can be possible? Maybe so, but it is really difficult if we consider the idea about "conservadorism".

Another student, Alessandra, gets her feminist education by watching videos on Youtube:

Gender is a hard topic to discuss at school, especially when dealing with close-minded societies such as ours. There is a lecture by a female Nigerian writer, called Chimamanda Ngozi Adichie, that talks about the issue of being a feminist and how gender defines the way we perceive social relationships. This lecture was recorded by TEDx, a communicative media to broadcast knowledge throughout the world, and it is called "Why should we all be feminists?". This talk is a very easy way to bring the discussion of gender to the classroom. The video brings a much-needed perspective about women's role in society, told by a woman who has lived many situations in which she had to deal with a lot of prejudice.

Talita, on the other hand, used the South American painter, Fernando Botero, to reflect on the aesthetics on gender:

First I introduce social diversity and cultural diversity too, because those points are very important to discuss gender in classroom. I would use Botero's pictures. Fernando Botero is a Colombian artist known for his large forms, especially "large women". The painter's work will help me to talk about stereotypes of the body in our society.

2. https://www.youtube.com/watch?v=Cf79KXBCIDg 
The students' narratives reveal their trajectories towards knowledge and the linguistic resources with which they interact. Moreover, these trajectories expose how people can develop agency in the contact zones (CANAGARAJAH, 2013, p. 154). As Guarnizo and Smith (1998) posit: "In the contemporary period, national boundaries are being constantly criss-crossed by processes of communication and exchange that do not include actual bodily movement, such as capital expansion, Internet, and other telecommunications". (p. 14-15). And they go on:

\footnotetext{
Moreover, recall that transnational flows are not limited to transmigrants bodily geographic mobility. They also include multiple exchanges of monetary and non-monetary resources, material and symbolic objects, commodities and cultural values...So too may the continuous flow of ideas and information provided by global media, ethnic tourism, and religious or secular festivals and rituals. All of these mechanisms have played a role in the re-emergence of transnational ties. (GUARNIZO \& SMITH, 1998, p.19)
}

Therefore, transnational literacy, in the era of globalization, can be defined as the expansion of our interpretations of reality by getting in touch with knowledges and cultures that are not part of our immediate milieu, but that flow globally, not only through the movement of bodies but through the circulation of information that new technologies afford. In this way, transnational literacies can be seen as an expansion of critical literacy, an expansion of our capacity to interpret the world from various perspectives that are culturally remote from our own.

\section{NARRATIVES AS GATEWAYS TO TRANSCULTURAL LITERACIES AND MULTIPLE PERSPECTIVES IN THE ACADEMIC CONTEXT}

A writing course in the academy is usually structured around linguistic and theoretical knowledge that the students must acquire in order to become competent scientific writers in English. This approach teaches important issues in writing such as citing correctly to avoid plagiarism and writing in a cohesive and coherent form, together with developing the student's argumentative, analytical and synthetical techniques. Undoubtedly, the structural aspect of the teaching methods persist and their focus is either on elements of writing (such as argument, cause and effect, opening paragraphs, references and quotations etc) or on accuracy in writing (adverbs, nouns and adjectives, punctuation, relative pronouns etc). How can a course work on these topics while focusing mainly on the narrative expression of the students' own experiences in the educational context? This question was deemed fit since the group was characterized by linguistic and cultural diversity in its oral and written linguistic expression in English. There were students that 
communicated meaning fluently and others whose communicative skills in English weren't the ones conventionally thought of as fit for the course.

Endorsing Jerome Bruner's (1990) theory on narratives seemed at that moment the right choice. The American psychologist's theory on the narratives that a community produces are interpretations of what he coined "cultural or folk psychology". He defines cultures as symbolic systems human beings adopt to perform symbolic activities which they furthermore employ in order to construct and make sense of the world and of themselves (BRUNER, p. 2). Theoretically, Bruner works in the interstices of psychology and "its sister interpretive disciplines in the humanities and in the social sciences" (BRUNER, p. 2). He emphasizes the centrality of meaning and valorizes the "intellectual reflex of academic psychology to redefine man and his mind in the light of new social requirements" (p. 6). This means that when people encounter the world and each other, there are meaningmaking processes taking place that are the fruit of these people's belonging to specific cultural groups and their folk psychology.

Cultures seek to achieve social stability and use narratives as a form of acknowledging human differences and trying to match their interpretations to the prevailing moral codes and social institutions of each culture. Narratives are employed by cultures in order to communicate to the different participants the values and moral code of the specific culture.

The most important aspect of folk psychology is its focus on what people say, the narratives they construct about their lives, the reasons they feel motivate them to act the way they do and the narratives they construct about other people's lives. Similarly, folk psychology is not interested in understanding what people do but is keen on figuring out what people say they do (BRUNER, 1990, p. 16). Narratives are at the center and not doings, since, for Bruner, in order for us to approach the structures of meaning of another culture, we should not try to interpret alone its cultural expressions but should let the natives of that culture, heterogeneous as they may be, say what they are doing and how they interpret the world they live in. Culturally oriented psychology perceives saying and doing as a unit that gives some access to the symbolic actions this culture has adopted.

Perceiving the teaching context as a borderland site between the academic culture and students' culture, this research was interested in student narrations about their educational and academic experiences. It reflected on how students could broaden these experiences by getting to know how people theoretically puzzle over these themes. The educational environment has long been seen as a meeting space with difference in all kinds of levels: intellectual, linguistic, social, 
cultural, gender, sexual etc. In the case study, theorizing about our English language academic writing course also turned into a contact zone between academic and community literacy practices. An exchange between standardized academic English language and emergent englishes practiced by the students fueled our talks on language and its rising grammars.

Some of the questions that steered our discussions were: Which discourses would make us get a glimpse and a partial understanding of the future community of English teachers that are formed in our institution? What kind of narratives could take us to a sharing of knowledges with the mobilization and complexification of our understanding of aspects of the educational environment where teachers move?

Folk psychology through the students' narratives of experience on educational matters would be cultural psychology's open-mindedness and willingness to construct knowledge from multiple perspectives. This cognitive revolution revolves around the concept of meaning and the processes of its construction. The narratives that the students produced in relation to "Critical Literacy and Teaching", one of the generative topics we discussed in class and the students wrote about, brought on the table some of the transnational cultural readings they make of the didactic material they have used as teachers or students. Fernanda, for example, points out that the food presented in the didactic book does not represent the kind of food her family, which belongs to a certain social class, consumes. Since there is little identification with her own eating habits, Fernanda becomes critical of the choice of food presented:

In addition, the book presents several situations with a lot of food that do not belong to Brazilian culture and they are usually consumed by rich people too, such as sour cream, buffalo wings, grilled tuna, broiled salmon and many others. What is the purpose of the book to show foods that are not consumed by most of Brazilians on a course made for Brazilians? Why do they always show foods that are consumed by rich people and that are from another culture? I have a feeling that the intention is to undervalue the poorer class and value the richer one. Not only this, but also do not value the culture of our country.

In another narrative, Alessandra reveals how didactic material has a western perspective on the cultures represented. Other cultures are depicted in the teaching apparatus in order to celebrate liberal, modern multiculturalism. As Fernandes (2018) affirms, although the trend nowadays is to be multicultural in the material that teaches us the English language, the perspective of this material is implicitly exalting Western cultures in comparison to the "exotic" ones. In the example below, Alessandra refers to a chapter in the book that talks about rickshaw pullers:

There is a text with images on Unit 7 about Rickshaws. They are a type of transportation used in India. The book says that only poor and middle-class people use this kind of transportation 
and that the ones that "drive" it are miserable people. They keep on talking about how Rickshaws are not good for the traffic in India and that the government is trying to take them out of the streets. While the text talks about how the Rickshaw "drivers" are miserable, they do not go deep into that and just analyse the people who use the transportation and what the government think of them.

It's important to emphasize that the students shared their narratives in class with their classmates by reading their texts. These were discussions, therefore, that emerged from the different perspectives the students brought to class. An exchange of views, opinions and perspectives emerged that turned the academic writing classroom into a contact zone.

\section{FINAL CONSIDERATIONS}

A postmodern take on transnational education requests a revision of "the Cartesian cartography of spatial science" (SOJA, 1989, p. 7), since transnational movements in the era of globalization and digitalization request a dematerialization of the nation state as a unit. Postmodern transnational geographies should take into consideration not only physical movements of bodies across nations, but also the means through which humans access transnational experiences through local and internal actions: trips to the local library, for instance, or imagined ancestral connections, as exemplified in the writings of the students in this study.

Our being-in-the-world follows transnational trajectories that are not only physically multi-layered but also metaphysically intriguing. Those trajectories that seek knowledges outside of the local are an expression of human geographies and can be studied through the narrativization of human experiences that depict such paths bodies and imagination take. Our thoughts and our actions, intertwined with reality and narratives, can reveal social practices that seek transnational knowledges acquired conventionally or unconventionally. In a global world of geographically uneven development, transnational literacies are reinvented by subjectivities.

\section{$\overline{\text { REFERENCES }}$}

ALCOFF, L.M. (2010) New Epistemologies: Post-Positivist Accounts of Identity. In Wetherell, M. and Mohanty, C.T. (Ed.), The Sage Handbook of Identities. Los Angeles and London: Sage Publications.

BOURDIEU, P. (1991) Language and Symbolic Power. Cambridge: Harvard University Press 
BRASIL. Ministério da Educação. Secretaria de Ensino Superior. (2014). A democratização e expansão da educação superior no país: 2003 - 2014. (Balanço Social 2003-2014). Brasília, DF. Recuperado de http://portal.mec.gov.br/index.php?option=com_doc man\&view $=$ download $\&$ alias $=16762$-balanco-socialsesu-2003-2014\&Itemid $=30192$

BRUNER, J. (1990) Acts of meaning. Cambridge: Harvard University Press.

CANAGARAJAH, S. (2013) Translingual Practice: global englishes and cosmopolitan relations. London \& New York: Routledge.

DUBOC, A.P.M. (2013) Teaching with an Attitude: finding ways to the conundrum of a postmodern curriculum. Creative education, Vol.4, No.12B, p. 58-65.

FERNANDES, G.R.R. (2018) Representações de Cultura em Livros Didáticos de Português Língua Estrangeira e Inglês Lingua Estrangeira: entrecruzamento de aspectos dos discursos fundadores das nações brasileiras e estadunidense. Dissertação de Mestrado em Letras. FFLCH, Universidade de São Paulo, São Paulo.

FREIRE, P. (2005) A Pedagogia dos Oprimidos. Rio de Janeiro: Paz e Terra.

GARCÍA, O. \& WEI, L. (2014) Translanguaging: language, bilingualism, and education. New York, NY: Palgrave MacMillan.

GIROUX, H.A. (1988) Teachers as Intellectuals: Towards a Critical Pedagogy of Learning. Connecricut \& London: Bergin \& Garvey Publishers.

GUARNIZO, L.E., \& SMITH, M.P. (1998) The locations of transnationalism. In M. P. Smith \& L. E. Guarnizo (Eds.), Transnationalism from below: Comparative urban and community research. New Brunswick, NJ: Transaction Publishers.

IRWIN, J. (2012) Paulo Freire's pbilosopby of education: origins, developments impacts and legacies. London and New York: Continuum.

LOW, S.M. \& LAWRENCE-ZUNIGA, D. (Eds) (2003) The Anthropology of Space and Place: Locating Culture. Oxford: Blackwell Publishing.

MAKONI, S. and PENNYCOOK, A. (2007) Disinventing and Reconstituting Languages. Clevedon, UK: Multilingual Matters.

NGUGI, wa Thiong'o. (1986) Decolonizing the Mind: the politics of language in African literature. Nairobi: Heinemann Kenya. 
PRATT, M.L. (1992) Imperial Eyes: Travel Writing and Transculturation. New York: Routledge.

SILVA, T.T. (1999) Documentos de Identidade: uma introdução às teorias do currículo. Belo Horizonte: Autêntica.

SOJA, E. (1989) Postmodern Geograpbies: the reassertion of space in critical social theory. London \& New York: Verso.

THE RIO TIMES. (2017) Editorial: who cares about Brazil? Available at: https:// riotimesonline.com/brazil-news/opinion-editorial/editorial-who-cares-about-brazil. Access on: Feb. $14^{\text {th }} 2019$.

WARRINER, D.S. (2007) Transnational literacies: Immigration, language learning, and identity. Linguistics and Education, 18(3-4), 201-214.

Recebido: 27/11/2018

Aceito: 10/03/2019

Publicado: 29/03/2019 